\title{
Pelatihan Entri Data Website Dengan Wordpress pada Balai Kebun Raya Baturraden
}

\author{
Website Data Entry Training with WordPress \\ at the Baturraden Botanical Garden Hall
}

\author{
Dimara Kusuma Hakim \\ Program Studi Teknik Informatika, Fakultas Teknik dan Sains, Universitas Muhammadiyah Purwokerto \\ Jl. Raya Dukuh Waluh, Kembaran 53182, Indonesia. \\ email: DimaraKusumaHakim@gmail.com
}

\section{ABSTRAK}

Kebun Raya Baturraden merupakan tempat konservasi yang menyimpan keanekaragaman hayati khas daerah Jawa Tengah. Pelestariannya harus terus dikawal dengan baik dengan komitmen bersama antara pemerintah daerah, dewan perwakilan rakyat daerah, dan LIPI.

Suatu instansi biasanya memerlukan suatu media agar lebih dikenal oleh masyarakat. Untuk lebih mendekatkan diri ke masyarakat serta agar masyarakat lebih mengenal seluk beluk mengenai instansi, maka biasanya akan diadakan berbagai acara yang melibatkan sejumlah masyarakat. Acara tersebut dapat berupa acara penggalangan dana, acara hiburan, acara pameran, kuliner dan sebagainya. Tentunya untuk mengadakan acara yang dapat populer di tengah masyarakat akan membutuhkan dana dan tenaga profesional yang tidak sedikit. Instansi juga akan membutuhkan waktu yang cukup lama dalam merencakan acara tersebut agar dapat menjadi sukses di masyarakat. Selain membuat acara di tengah kehidupan masyarakat, ada alternatif lain yang dapat dilakukan instansi yang merupakan langkah mudah agar dapat dikenal oleh masyarakat yaitu menggunakan website.

Secara teknologi, pembuatan website dapat dilakukan oleh instansi, akan tetapi proses untuk perawatannya: mengisi konten (berita) adalah hal yang seringkali sulit dilakukan jika tidak menyiapkan SDM (Sumber Daya Manusia) dari awal dibangunnya website tersebut. Kondisi yang diharapkan pada Balai Kebun Raya Baturraden tersebut menuntut berbagai hal dalam pengelolaan instansi. Balai Kebun Raya Baturraden perlu menyiapkan Sumber Daya Manusia (SDM) untuk mengelola website, kegiatan ini memberikan solusi bagi SDM untuk membuat website dan pengelolaan konten.

Kata Kunci: pelatihan, website, penyiapan sdm

\section{ABSTRACT}

Baturraden Botanical Garden is a conservation place that stores the biodiversity typical of the Central Java region. Its preservation must continue to be well guarded with a joint commitment between the local government, the regional people's representative council, and LIPI.

An agency usually requires a media to be better known by the public. In order to get closer to the community and so that people are more familiar with the ins and outs of agencies, usually various events will be held involving a number of communities. These events can be in the form of fundraising events, entertainment events, exhibitions, culinary events and so on. Of course, to hold an event that can be popular in the community will require a lot of funds and professional staff. Agencies will also need a long time planning the event in order to be successful in society. In addition to organizing events in the midst 
of people's lives, there is another alternative that agencies can take which is an easy step to be recognized by the public, namely using a website.

Technologically, making websites can be done by agencies, but the process for maintenance: filling in content (news) is something that is often difficult to do if you do not prepare HR (Human Resources) from the beginning of the website's construction. The conditions expected at the Baturraden Botanical Garden Hall require various things in the management of the agency. The Baturraden Botanical Garden Center needs to prepare Human Resources (HR) to manage the website, this activity provides solutions for HR to create websites and manage content.

\section{Keywords: training, website, staff preparation}

\section{Pendahuluan}

Kebun Raya Baturraden merupakan tempat konservasi yang menyimpan keanekaragaman hayati khas daerah Jawa Tengah. Pelestariannya harus terus dikawal dengan baik dengan komitmen bersama antara pemerintah daerah, dewan perwakilan rakyat daerah, dan LIPI. Kebun Raya ini adalah salah satu kebun raya yang telah dikelola dengan baik. Keberadaannya sangat membantu konservasi karena tutupan hutan di Jawa hanya tinggal 7 persen saja. Kebun raya ini menjadi warisan bagi rakyat untuk menjaga kelestarian alam. Kebun Raya yang telah dirintis sejak 2001 ini, merupakan hasil kerja sama antara Kementerian Lingkungan Hidup dan Kehutanan, LIPI, Perhutani, dan juga pemerintah daerah. Saat ini, koleksi kebun raya ini sebanyak 773 spesies dengan 3300 spesimen.

Kebun Raya Baturraden berada di Desa Kemutug Lor, Kecamatan Baturraden, Kabupaten Banyumas, berbatasan dengan Lokawisata Baturraden dan Bumi Perkemahan Baturraden. Luas kebun raya itu sekitar 143,5 hektar dan terletak di kawasan Wana Wisata Perum Perhutani yang merupakan perkebunan pinus (Pinus merkusii), dammar (Agathis borneensis), dan rasamala (Altingia excelsa), serta beberapa jenis rotan sebagai sisipan. Kebun Raya Baturraden telah ditetapkan sebagai kawasan konservasi ex-situ untuk flora pegunungan Jawa.

Suatu instansi biasanya memerlukan suatu media agar lebih dikenal oleh masyarakat. Untuk lebih mendekatkan diri ke masyarakat serta agar masyarakat lebih mengenal seluk beluk mengenai instansi, maka biasanya akan diadakan berbagai acara yang melibatkan sejumlah masyarakat. Acara tersebut dapat berupa acara penggalangan dana, acara hiburan, acara pameran, kuliner dan sebagainya. Tentunya untuk mengadakan acara yang dapat populer di tengah masyarakat akan membutuhkan dana dan tenaga profesional yang tidak sedikit. Instansi juga akan membutuhkan waktu yang cukup lama dalam merencakan acara tersebut agar dapat menjadi sukses di masyarakat. Selain membuat acara di tengah kehidupan masyarakat, ada alternatif lain yang dapat dilakukan instansi yang merupakan langkah mudah agar dapat dikenal oleh masyarakat yaitu menggunakan website.

Website adalah media komunikasi instansi kepada masyarakat. Maraknya penjualan gadget di masyarakat membuat teknologi kini telah menjadi barang yang tidak asing di tengah masyarakat. Ponsel pintar misalnya, dapat memberikan fasilitas agar orang-orang dapat mencari informasi dari mana saja mereka berada. Jaringan internet, menghubungkan semua orang di dunia dalam satu komunitas. Orang bisa mengakses informasi dari ujung dunia hanya dengan menggunakan perangkat komunikasi yang mereka miliki dengan mudah. Hal ini dapat digunakan oleh perusahaan atau instansi dalam memperkenalkan dirinya di tengah masyarakat. Instansi tersebut dapat membuat website yang profesional. Pada website dapat dimasukkan sejarah mengenai instansi, siapa saja yang berperan di dalamnya, usaha seperti apa yang ditekuni, publikasi untuk kegiatan di masyarakat dan masih banyak lagi. 
Sosial media menjadikan suatu fenomena dalam kehidupan masyarakat yang membuat jarak tidak lagi berarti. Kini orang-orang bisa terhubung, saling berbagai pengalaman dalam kehidupannya dengan mudah dari Facebook atau Twitter atau sosial media yang lain. Hal ini juga dapat digunakan oleh instansi untuk berinteraksi langsung dengan masyarakat. Dapat diberikan pengumuman atau berita dengan membagikannya di sosial media, dan orang-orang yang telah terhubung di sosial media tersebut akan dengan mudah memberikan komentar balik mengenai acara tersebut. Komentar tersebut akan sangat membantu anda dalam membangun acara atau promo yang lebih baik.

Secara teknologi, pembuatan website dapat dilakukan oleh instansi, akan tetapi proses untuk perawatannya: mengisi konten (berita) adalah hal yang seringkali sulit dilakukan jika tidak menyiapkan SDM (Sumber Daya Manusia) dari awal dibangunnya website tersebut.

Kondisi yang diharapkan pada Balai Kebun Raya Baturraden tersebut menuntut berbagai hal dalam pengelolaan instansi. Balai Kebun Raya Baturraden perlu menyiapkan Sumber Daya Manusia (SDM) untuk mengelola website, kegiatan ini memberikan solusi bagi SDM untuk membuat website dan pengelolaan konten.

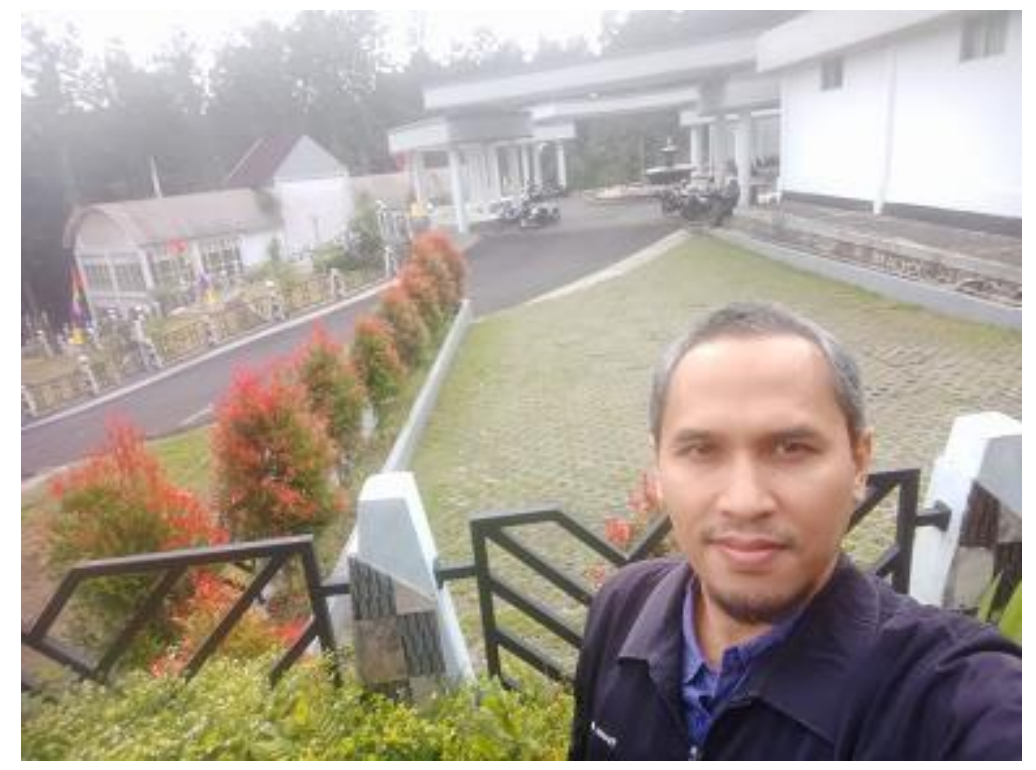

Gambar 1. Kantor Balai Kebun Raya Baturraden 


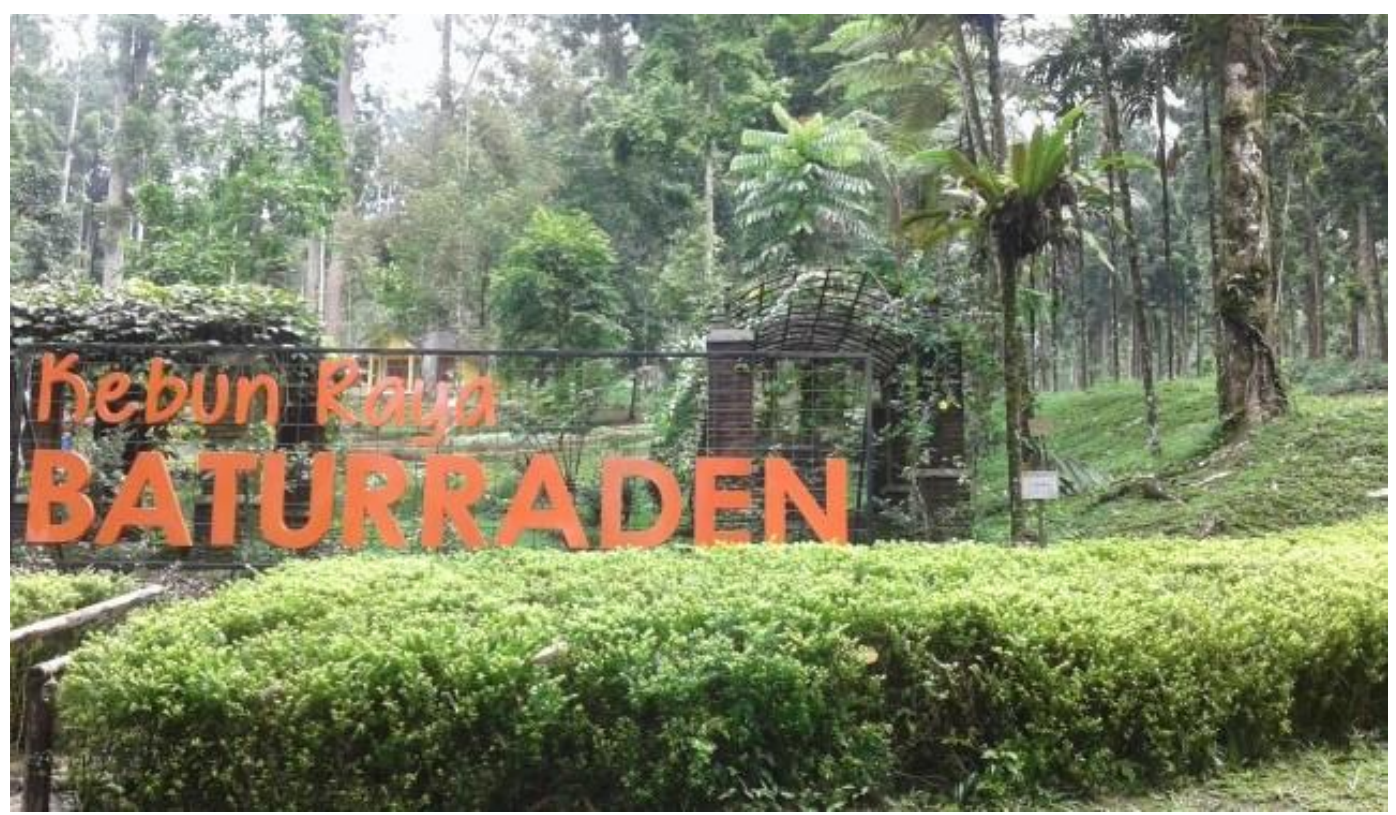

Gambar 2. Kebun Raya Baturraden

\section{Metode}

Metode pengabdian yang digunakan adalah dan Pelatihan (berupa kegiatan yang disertai dengan demonstrasi atau percontohan untuk menghasilkan keterampilan tertentu).

Pendidikan dan pelatihan ini menggunakan metode ceramah, demonstrasi, tanya jawab (diskusi), dan praktik langsung. Adapun teknik pelaksanaan kegiatan ini menggunakan langkah-langkah:

1. Pengenalan secara singkat tentang internet

2. Pengenalan software Wordpress dan Wordpress Android

3. Demonstrasi dan praktik langsung

4. Membuat Website

5. Mengisi kontan

\section{Hasil dan Pembahasan}

Kegiatan pelatihan ini dilaksanakan dengan jadwal:

Pelatihan sesi ke-1 : Pengenalan Singkat Internet

Pelatihan sesi ke-2 : Pengenalan Wordpress

Pelatihan sesi ke-3 : Demonstrasi dan praktek

Pelatihan sesi ke-4 : Studi kasus pembuatan web dan konten

Kegiatan dilaksanakan mulai pukul 8.30 - 14.30 yang diikuti oleh 15 orang peserta. Hal ini menandakan begitu antusiasnya para staf dalam menyikapi dan merespon kegiatan ini. Selama pelatihan, peserta mendapatkan fasilitas makalah materi, beserta tutor/instruktur dan asisten, snack, dan sertifikat. Instruktur dan asisten dilibatkan dengan maksud agar kegiatan pelatihan ini mempunyai dampak yang benar-benar dapat dirasakan oleh peserta karena kesulitan-kesulitan peserta saat mengikuti pelatihan dapat teratasi dan peserta mendapatkan bimbingan yang optimal. 


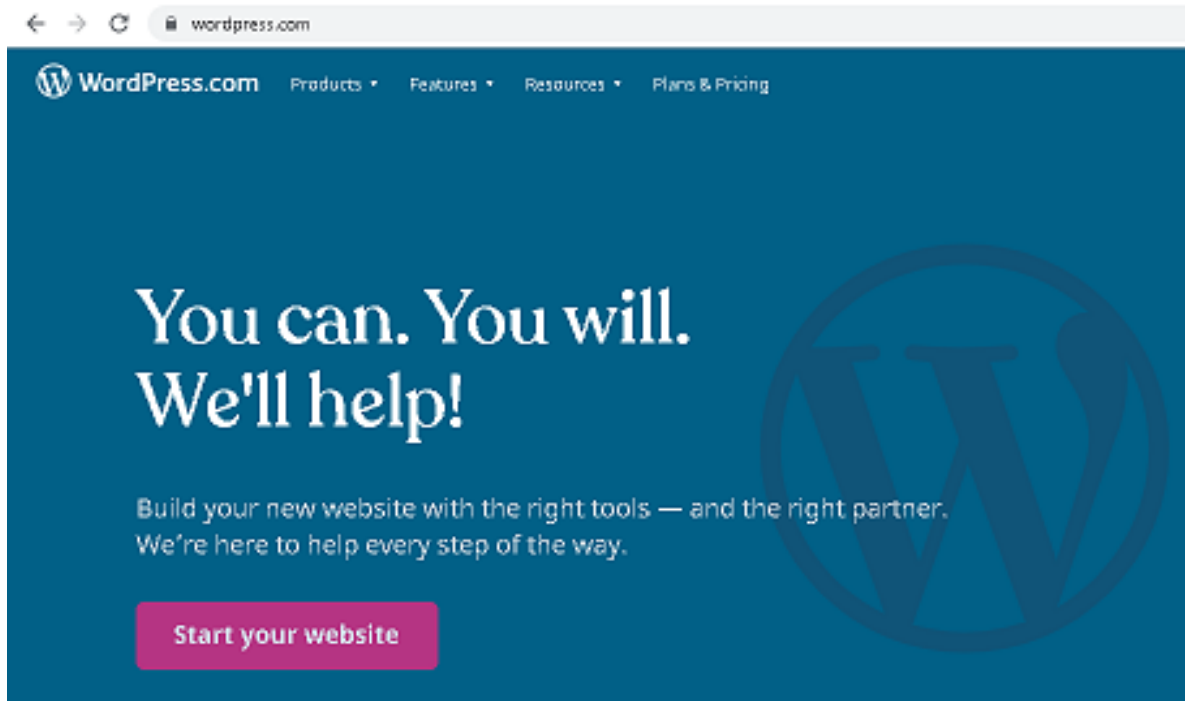

Gambar 3. Daftar akun Wordpress

\section{(11)}

Give your blog an address

Enter your blog's name or some keywords that describe it to get started.

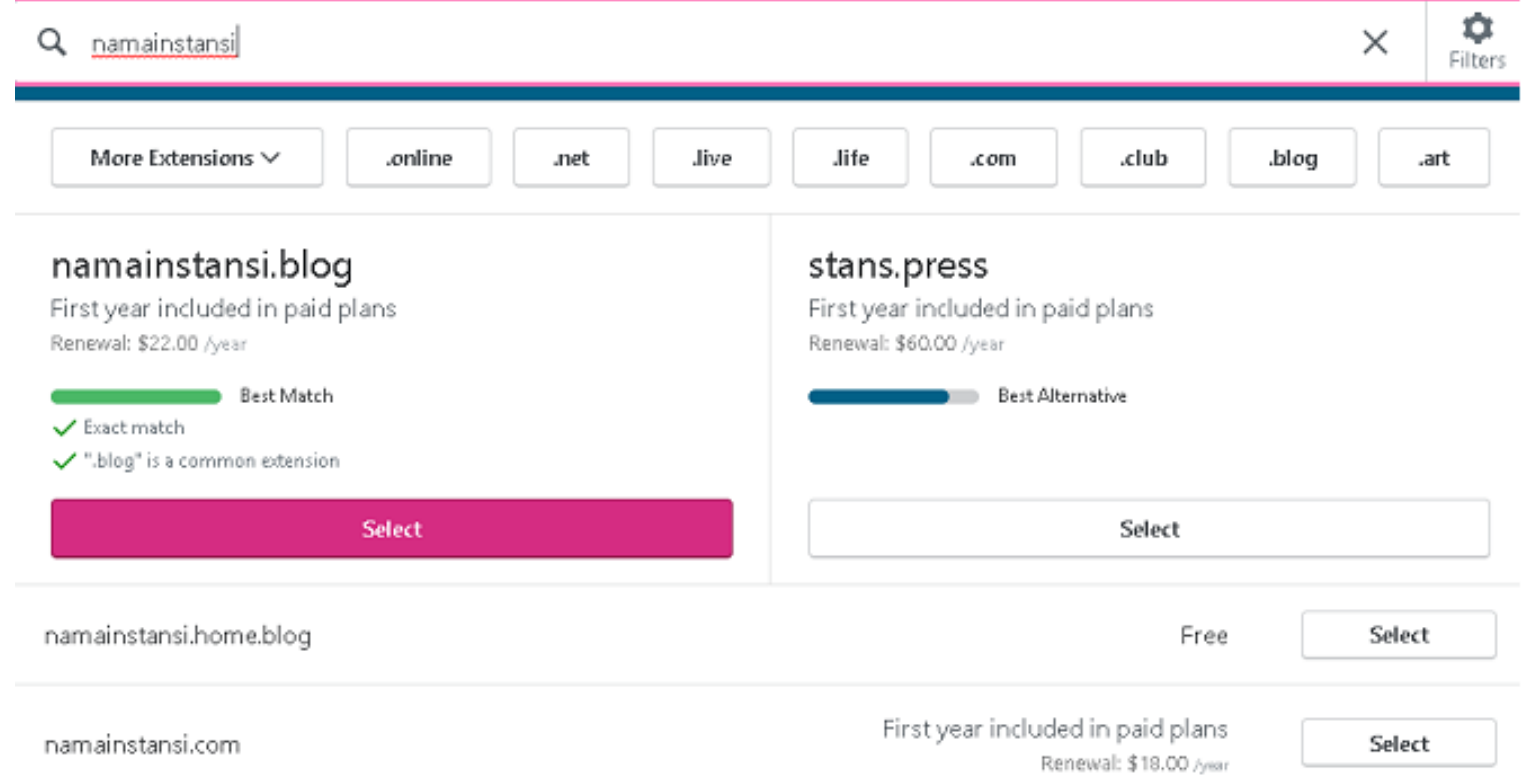

Gambar 4. Pendaftaran Wordpress 


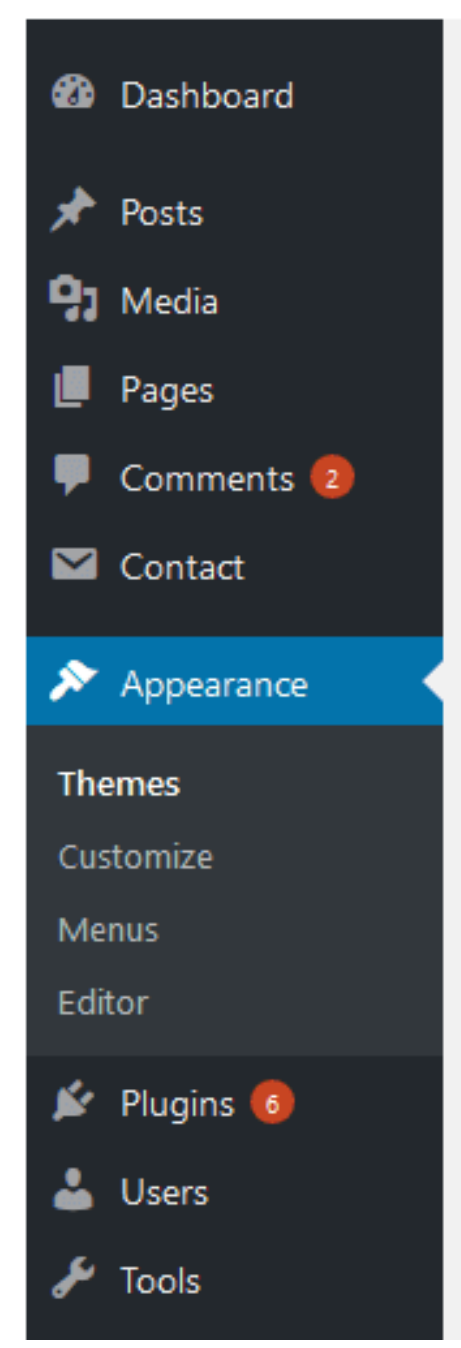

\section{Add Themes Upload Theme}

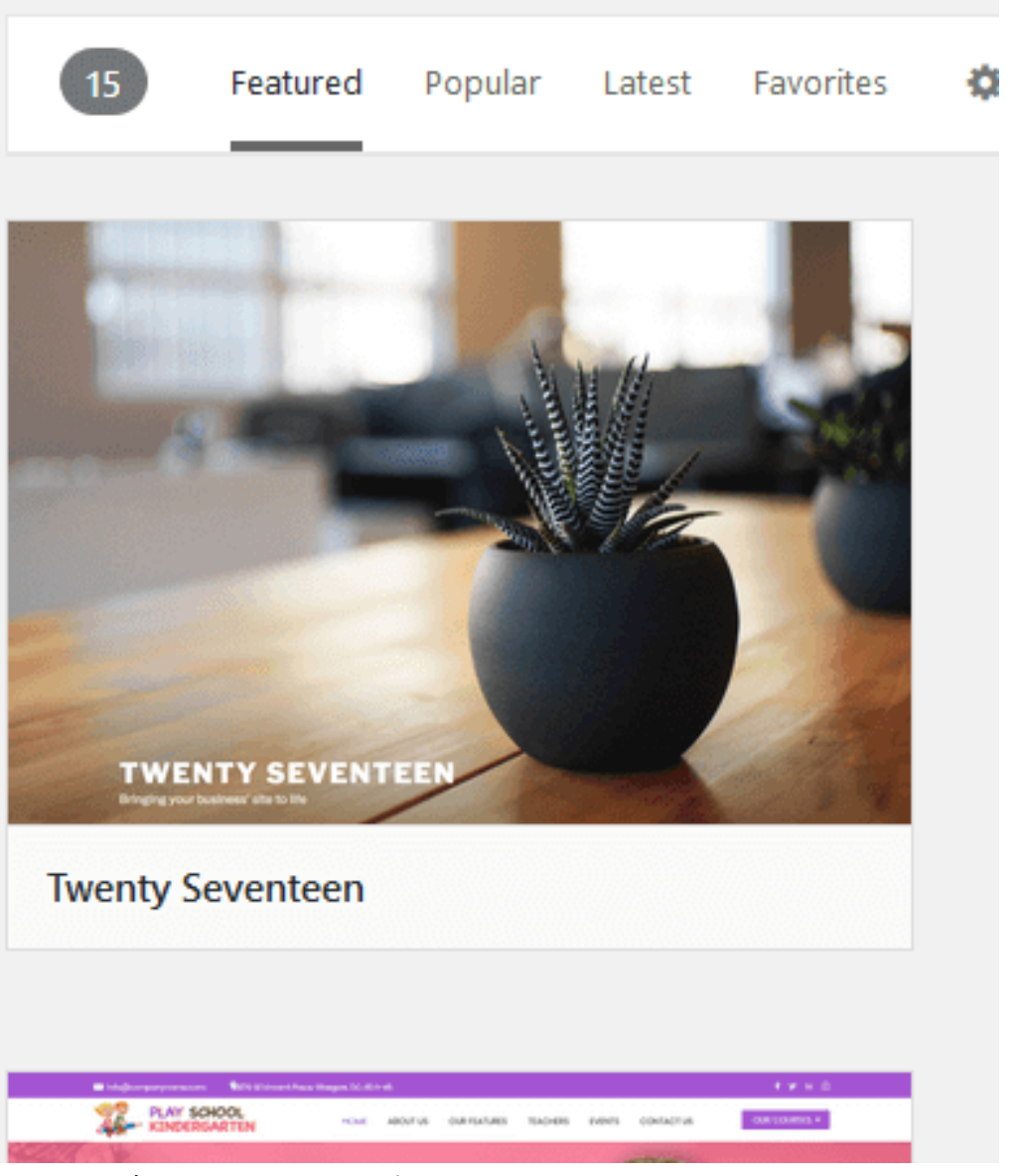

Gambar 5. Setting Website 


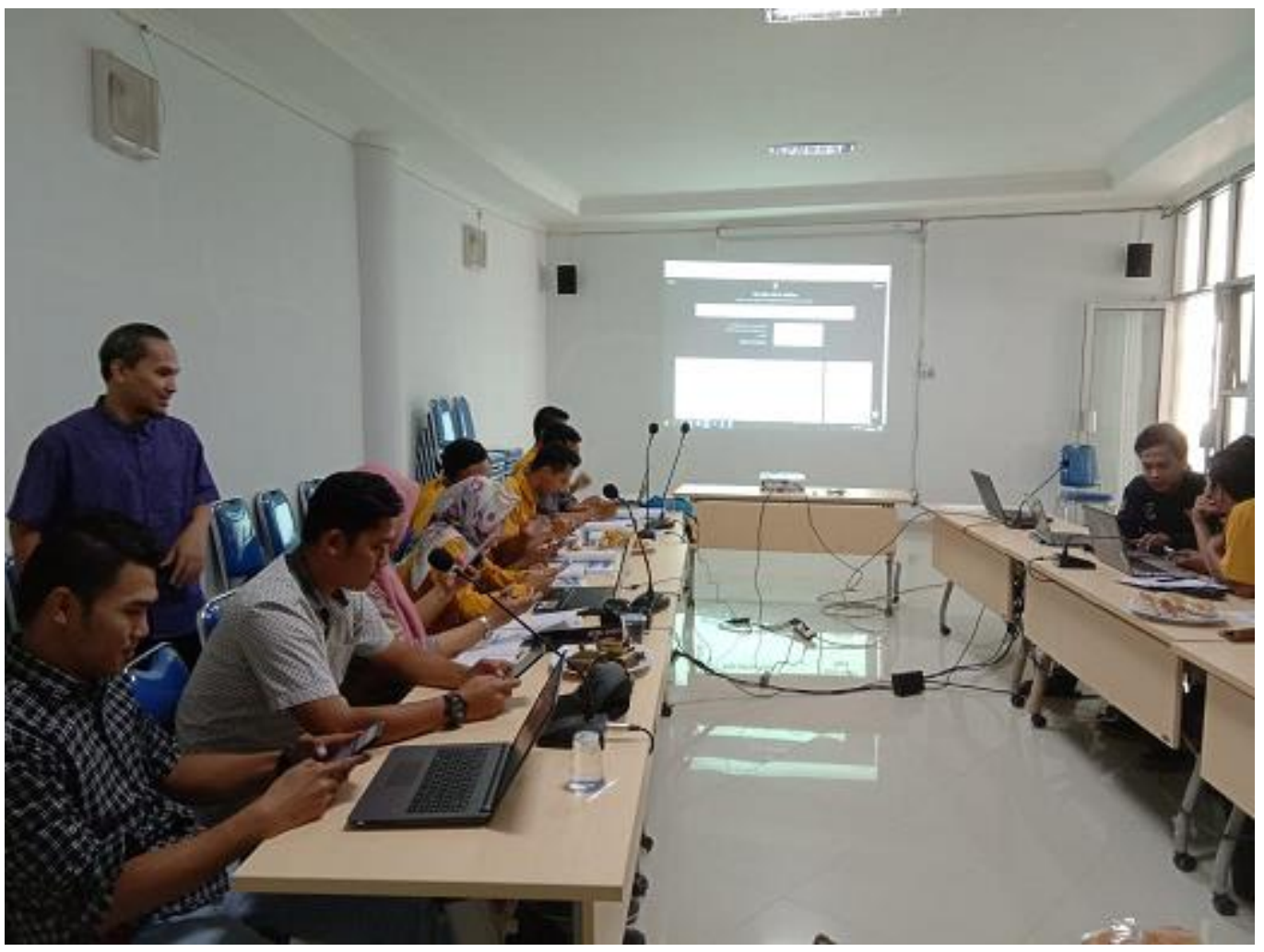

Gambar 6. Kegiatan Pelatihan

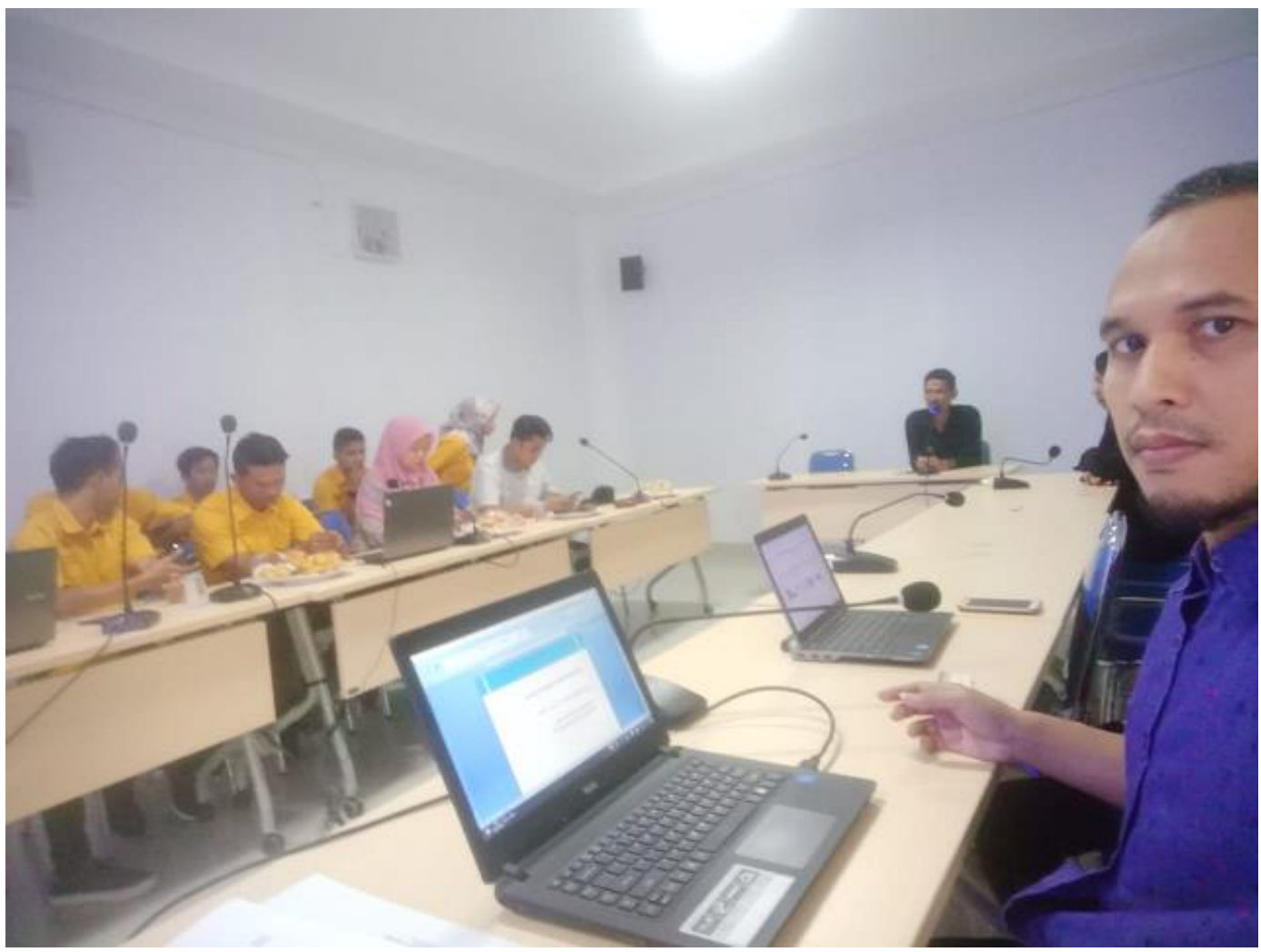

Gambar 7. Sambutan dari Kepala Balai 


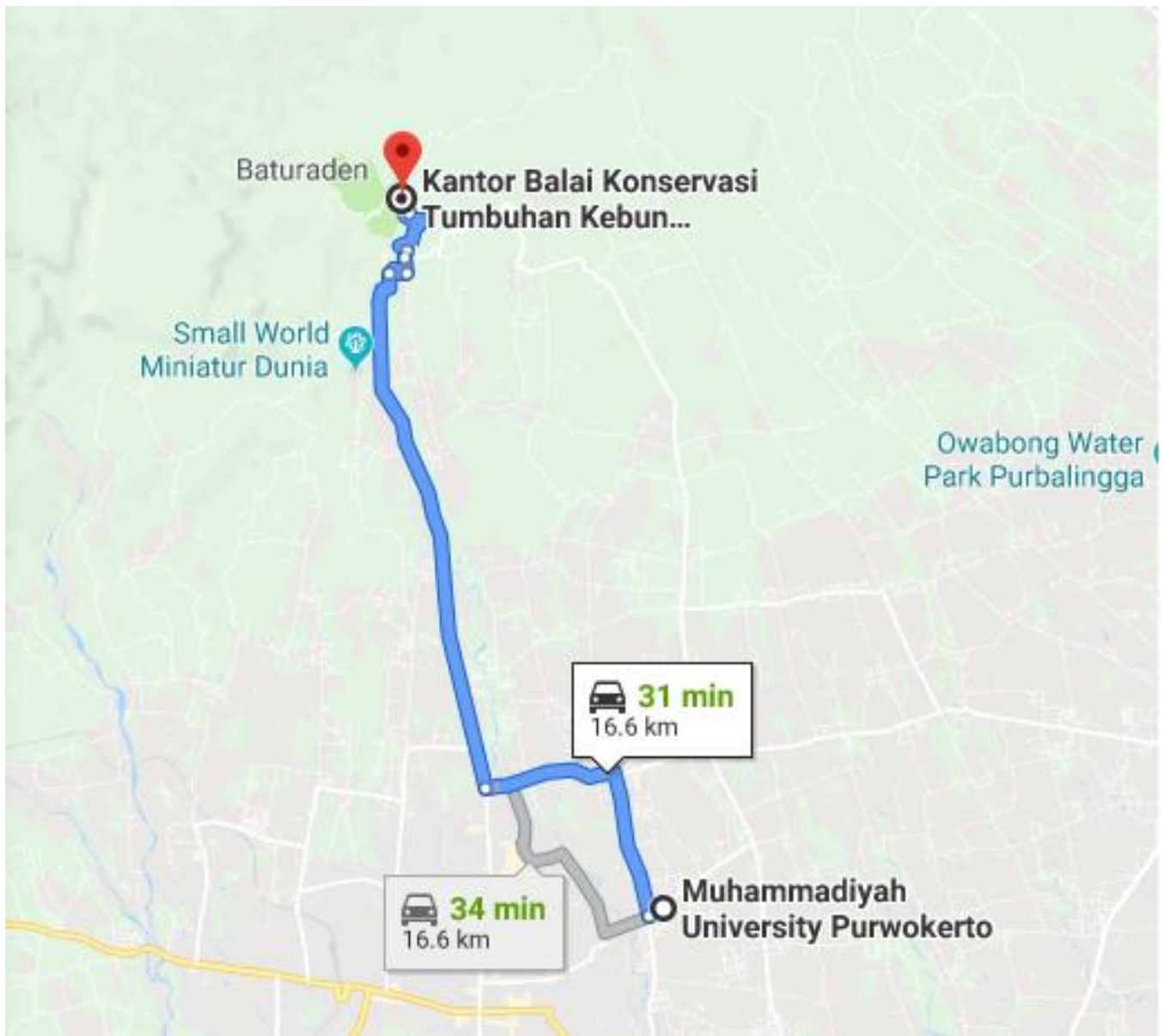

Gambar 8. Lokasi Mitra, Jl. Pancuran Tujuh-Wanawisata Baturraden

\section{Kesimpulan}

Berdasarkan hasil evaluasi yang dilakukan, maka dapat ditarik kesimpulan bahwa kegiatan pelatihan diterima dengan baik oleh para peserta pelatihan. Melihat tanggapan dan juga saran dari para peserta pelatihan ini, maka perlu diadakan pelatihan-pelatihan sejenis.

\section{UCAPAN TERIMA KASIH}

Ucapan terima kasih kami sampaikan kepada Balai Kebun Raya Baturraden yang telah mendukung kegiatan ini. 


\section{DAFTAR PUSTAKA}

Niaga Hoster. (2015). Tutorial Wordpress Untuk Pemula. Yogyakarta: Niagaweb.

Niaga Hoster. (2019). Cara Membuat Menu di Wordpress. URL:

https://www.niagahoster.co.id/blog/cara-membuat-menu-di-wordpress/ (diakses: 5 Desember 2020).

Niaga Hoster. (2019). Cara Membuat Wordpress. URL: https://www.niagahoster.co.id/blog/caramembuat-wordpress/ (diakses: 5 Desember 2020).

WP Beginner. (2019). How to Add a ew Post in Wordpress and Utilize All the Fatures. URL: https://www.wpbeginner.com/beginners-guide/how-to-add-a-new-post-in-wordpress-andutilize-all-the-features/ (diakses: 5 Desember 2020). 